\title{
Phosphoglycopeptide, a major constituent of the spermatophoric plasma of the octopus (Octopus dofleini martini)
}

\author{
D. E. Brooks, M. E. Tate, T. Mann* and A. W. Martin* \\ Departments of Animal Physiology and Agricultural Biochemistry, University of Adelaide, \\ Waite Agricultural Institute, Glen Osmond, South Australia 5064, and *Department of \\ Zoology, University of Washington, Seattle 98195, U.S.A.
}

\begin{abstract}
Summary. A phosphoglycopeptide, accounting for approximately $90 \%$ of the characteristically high content of acid-soluble organically-bound phosphorus in the octopus spermatophoric plasma $(4 \mathrm{mg} \mathrm{P} / \mathrm{ml})$, was identified. Electrophoretic and chromatographic purification, followed by chemical and enzymic hydrolysis, yielded D-galactose phosphate as a degradation product. The galactose and peptide moieties of the compound were linked via a phosphoryl rather than a glycosidic linkage but the peptide was devoid of aromatic amino acids.
\end{abstract}

\section{Introduction}

Spermatophoric plasma, which is the fluid surrounding the sperm rope within the spermatophore of the giant octopus, Octopus dofleini martini, exhibits certain unusual physico-chemical properties: the dry weight content (about $25 \mathrm{~g} / 100 \mathrm{ml}$ ), relative density $(1.080-1.087)$ and viscosity $(\mathrm{c} \mathrm{P}=10.5-16.9)$ are all much higher than are generally encountered in biological fluids. The high osmolality $(670 \mathrm{mosmol} / \mathrm{kg})$ is mostly caused by substances other than electrolytes, i.e. glycoproteins and glycopeptides containing bound carbohydrate and amino sugar, but little sialic acid (Mann, Martin \& Thiersch, 1970). Another characteristic feature of the spermatophoric plasma is the presence of a considerable amount of organically-bound, but trichloroacetic acid-extractable, phosphate, about $100 \mu \mathrm{mol} \mathrm{P} / \mathrm{ml}$, of which roughly $10 \%$ has been identified as glycerophosphocholine (Brooks, Mann \& Martin, 1974). The present study provides evidence that most of the remaining acid-soluble phosphate occurs in the form of phosphoglycopeptide, in which phosphate is bound to galactose. The study is concerned with the isolation and partial chemical characterization of this unusual peptide, its origin in the male reproductive tract of the octopus, and its participation in the spermatophoric reaction when, as a result of sea-water influx into the intraspermatophoric compartment, the sperm rope is pushed forward from the proximal to the distal end of the spermatophore and finally ejected into the spermatophoric bladder.

\section{Materials and Methods}

The animals were trapped in the Puget Sound-San Juan Archipelago area. The methods of freeing the spermatophores from the male reproductive tract, and the terminology used in 
designating the accessory organs, genital fluids, component parts of the spermatophore and stages of the spermatophoric reaction, were those introduced by Mann et al. (1970).

\section{Chemicals and enzymes}

Dowex AG 1-X2 (200-400 mesh, $\mathrm{Cl}^{-}$form) and Dowex AG 50W-X8 (200-400 mesh, $\mathrm{H}^{+}$ form) were purchased from Bio Rad Laboratories, Richmond, California, U.S.A.; they were washed and the Dowex 1 converted to the formate form as described by Brooks (1970). Compounds for use as chromatographic standards as well as enzymes were obtained from Sigma Chemical Co., St Louis, Missouri, U.S.A., or Boehringer Mannheim Australia Pty Ltd, Melbourne, Australia. The enzymes used included pronase (Sigma, type VI from Streptomyces griseus; $45 \mathrm{U} / \mathrm{mg}$ ), trypsin (EC3.4.21.4; $1290 \mathrm{U} / \mathrm{mg}$ ), elastase (EC 3.4.21.11;23 U/mg), papain (EC 3.4.22.2; $20 \mathrm{U} / \mathrm{mg}$ ), ficin (EC 3.4.22.3;0.3 U/mg), lysozyme (EC 3.2.1.17; $22000 \mathrm{U} / \mathrm{mg}$ ), collagenase (EC 3.4.24.3; $115 \mathrm{U} / \mathrm{mg}$ ), bacterial alkaline phosphatase (EC 3.1.3.1;30 U/mg), snake venom phosphodiesterase (EC 3.1.4.1;0.24 U/mg), $\alpha$-galactosidase (EC 3.2.1.22; 27.5 $\mathrm{U} / \mathrm{mg}$ ), $\beta$-galactosidase (EC $3.2 .1 .23 ; 10 \mathrm{U} / \mathrm{mg}$ ), galactose dehydrogenase (EC 1.1.1.48; 5 $\mathrm{U} / \mathrm{mg}$ ), $\beta$-glucosidase (EC 3.2.1.21; 4.6 U/mg). The enzymes were diluted with $0.05 \mathrm{M}$ $\mathrm{NH}_{4} \mathrm{HCO}_{3}, \mathrm{pH} 7 \cdot 8$, or with $0.05 \mathrm{M}-\mathrm{NaHCO}_{3}$ adjusted to $\mathrm{pH} 6$ with $\mathrm{CO}_{2}$ before use.

\section{Analytical procedures}

Inorganic phosphate was determined in the presence of organic phosphate by the procedure of Berenblum \& Chain (1938) or in incinerated samples as described by Brooks (1970). Galactose was assayed by the spectrophotometric procedure of Bergmeyer (1974). Partitioning of material into organic (chloroform) and aqueous (water-methanol) phases was by the procedure of Bligh \& Dyer (1959) for the extraction of lipids. Protein was estimated by reaction with Coomassie Brilliant Blue G250 (Sedmak \& Grossberg, 1977) and using bovine serum albumin as the standard.

Procedure for the separation and purification of the acid-soluble phosphorus-containing fraction from spermatophoric plasma

Spermatophoric plasma $(6 \mathrm{ml})$ was precipitated with 0.25 volumes of $40 \%(\mathrm{w} / \mathrm{v})$ trichloroacetic acid. After centrifugation, excess trichloroacetic acid was extracted from the supernatant by shaking with 2 volumes of ether and repeating the extraction four times. The material was then passed through an ultrafiltration membrane with a nominal exclusion for compounds of molecular weight $>10000$ (PM 10 membrane in a model 52 dialysis cell from Amicon Corp., Lexington, Massachusetts, U.S.A., operated under $2.5 \times 10^{5} \mathrm{~Pa}$ of $\mathrm{N}_{2}$ ). The diffusate was passed through a column containing $3 \mathrm{ml}$ Dowex 1 and the column was washed through with water and the combined eluate was next added to a column containing $4 \mathrm{ml}$ Dowex 50. After washing through with $20 \mathrm{ml}$ water followed by $22 \mathrm{ml} 5 \mathrm{M}$-formic acid and $20 \mathrm{ml}$ water, the column was eluted with a gradient from $50 \mathrm{ml} 0.1 \mathrm{M}-\mathrm{NH}_{4} \mathrm{OH}$ to $50 \mathrm{ml} 0.5 \mathrm{M}-\mathrm{NH}_{4} \mathrm{OH}$ collected in $2.5 \mathrm{ml}$ fractions. Quantitative recovery of phosphorus was obtained in the fractions between 25 and $50 \mathrm{ml}$ effluent. These fractions were pooled and reduced in volume to $2.5 \mathrm{ml}$ on the rotary evaporator at $50^{\circ} \mathrm{C}$. This material was used for the subsequent analyses; it contained $3.9 \mathrm{mg}$ phosphorus $/ \mathrm{ml}$.

\section{Electrophoresis and chromatography}

Electrophoresis and chromatography on Whatman No. 1 paper was used for further separation of the phosphorus-containing material, but for preparative purposes Whatman 3MM 
was used; the appropriate areas were cut out and eluted with water after locating the spots by staining paper strips cut from edges.

The systems used for electrophoresis were: (a) $0.76 \mathrm{M}$-formic acid plus $1.03 \mathrm{M}$-acetic acid, pH 1.7 (Efron, 1968); (b) 0.1 M-citrate adjusted to $\mathrm{pH} 5.5$ with $\mathrm{NaOH}$; (c) 0.2 M-triethylamine-borate, $\mathrm{pH} 9.4$; (d) $0.05 \mathrm{M}-\mathrm{Na}_{2} \mathrm{CO}_{3}, 0.05 \mathrm{M}-\mathrm{NaHCO}_{3}, \mathrm{pH}$ 10. In general, separations were carried out at $2500 \mathrm{~V}$ for up to $1 \mathrm{~h}$. A mixture of standard compounds containing xylene cyanol FF, orange G, inorganic phosphate, fructose, ATP and 2deoxyadenosine was applied to each side of the paper before electrophoresis and other standards were added as appropriate. The origin was located by the position of fructose, except in system (c) where the position of 2-deoxyadenosine was taken as the origin. Mobilities are quoted relative to orange $G$ in the same $(+)$ or opposite $(-)$ direction.

Descending chromatographic systems included (a) $n$-butanol :acetic acid : water $(12: 3: 5$ by vol.) (Efron, 1968); (b) ethyl acetate :pyridine : water (10:4:3 by vol.) (Hough \& Jones, 1962); (c) phenol saturated with water (Block, Durrum \& Zweig, 1958); (d) phenol saturated with water : acetic acid : ethanol (50:5:6 by vol.) (Dawson, Hemington \& Davenport, 1962); (e) isopropanol : water: $\mathrm{NH}_{3}$ (7:2:1 by vol.) (Brown, Clark \& Letters, 1961); (f) $77 \%$ ethanol (Block et al., 1958). In some instances electrophoresis in system (a) was carried out before the chromatography of neutral sugars in order to remove interfering ions.

A variety of stains was used in initial investigations to locate spots, but for routine analysis the following were used: (a) examination under ultraviolet light; (b) $0.25 \%$ ninhydrin in acetone for primary amino groups (Toennies \& $\mathrm{Kolb}, 1951$ ); (c) the $\mathrm{AgNO}_{3}$ reagent for carbohydrates (Trevelyan, Procter \& Harrison, 1950); (d) the dip of Harrap (1960) for phosphorus-containing compounds; (e) the p-anisidine reagent for reducing sugars (Dawson, Elliott, Elliott \& Jones, 1969).

\section{Results}

\section{Properties of the acid-soluble phosphorus fraction obtained from the spermatophoric plasma}

The contents of spermatophores freshly removed from the spermatophoric sac were separated into sperm ropes and spermatophoric plasma by centrifugation. The sperm-free spermatophoric plasma had a high content of total phosphorus, determined after incineration with perchloric acid (Table 1). Virtually all of the phosphorus was organically bound since only $0.05 \%$ was present as inorganic phosphate (Table 1 ).

The bulk $(93 \%)$ of the total phosphorus was extractable into $10 \%$ trichloroacetic acid but none of this extracted phosphorus passed into the organic phase when the trichloroacetic extract was shaken with ether to remove the excess of this acid. Furthermore, when partitioned between chloroform and methanol/water according to Bligh \& Dyer (1959), the acid-soluble phosphorus remained in the aqueous phase, clearly indicating that it is unlikely to be a lipid.

Of the total amount of acid-soluble phosphorus, only 3\% was converted to inorganic phosphate by hydrolysis with $1 \mathrm{M}-\mathrm{HCl}$ for $1 \mathrm{~h}$ at $100^{\circ} \mathrm{C}$; the remainder was in a form difficult to hydrolyse.

It appeared that the phosphorus-containing compound was of relatively low molecular weight because it was (a) soluble in trichloroacetic acid, (b) not precipitated from acid extracts by ethanol ( $80 \%$ final concentration) and (c) able to pass through a cellophane dialysis sac and through the ultrafiltration membrane which excluded compounds of molecular weight $>10000$.

\section{Preliminary characterization of the phosphoglycopeptide}

The phosphorus-containing material purified from spermatophoric plasma as described in the 'Materials and Methods', gave a positive reaction with ninhydrin, but a negative reaction for secondary, tertiary and quaternary amines. In all cases after chromatography or electrophoresis 
Table 1. Distribution of inorganic and acid-soluble phosphorus in various tissues and fluids of the male octopus

\begin{tabular}{|c|c|c|}
\hline & \multicolumn{2}{|c|}{$\begin{array}{c}\text { Phosphorus } \\
\text { ( } \mathrm{mg} / \mathrm{ml} \text { or } \mathrm{mg} / \mathrm{g} \text { wet } \mathrm{wt} \text { ) }\end{array}$} \\
\hline & Inorganic & $\begin{array}{c}\text { Total } \\
\text { acid-soluble }\end{array}$ \\
\hline Blood & 0.008 & 0.007 \\
\hline Genital-bag fluid $\ddagger$ & 0.001 & 0.002 \\
\hline Testicular plasma§ & 0.138 & 0.179 \\
\hline Vas-deferens plasma $\S$ & 0.049 & 0.061 \\
\hline \multicolumn{3}{|l|}{ Seminal vesicleף } \\
\hline Tissue close to vas deferens & 0.028 & 0.206 \\
\hline Tissue close to the prostate & 0.115 & 0.216 \\
\hline $\begin{array}{l}\text { Spermatophoric plasma from } \\
\text { a spermatophore close } \\
\text { to the vas deferens }\end{array}$ & 0.005 & 0.136 \\
\hline $\begin{array}{l}\text { Spermatophoric plasma from } \\
\text { a spermatophore close to } \\
\text { the prostate }\end{array}$ & $\begin{array}{c}0.003^{*} \\
(0.001-0.005)\end{array}$ & $\begin{array}{c}0.012^{*} \\
(0.009-0.014)\end{array}$ \\
\hline \multicolumn{3}{|l|}{ Prostate $\dagger$} \\
\hline Tissue & 0.193 & 0.359 \\
\hline $\begin{array}{l}\text { Spermatophoric plasma from } \\
\text { a spermatophore in the prostate }\end{array}$ & $\begin{array}{c}0.008^{*} \\
(0.006-0.010)\end{array}$ & $\begin{array}{c}0.132^{*} \\
(0.125-0.139)\end{array}$ \\
\hline Spermatophoric sac & & \\
\hline $\begin{array}{l}\text { Spermatophoric plasma from } \\
\text { a mature spermatophore }\end{array}$ & $\begin{array}{c}0.002^{*} \\
(0.001-0.003)\end{array}$ & $\begin{array}{c}3 \cdot 75 \dagger \\
(2 \cdot 57-4 \cdot 53)\end{array}$ \\
\hline
\end{tabular}

Values are for $1,2^{*}$ or $3+$ animals with the range in parentheses. The detection limit of the assay was $0.0005 \mathrm{mg} \mathrm{P} / \mathrm{ml}$.

₹ Fluid inside the genital bag but outside the reproductive tract.

\$ Supernatant fluids after centrifugation of homogenized tissues.

II Spermatophoric gland system I (see Mann et al., 1970).

†† Spermatophoric gland system II (see Mann et al., 1970).

the phosphorus- and ninhydrin-staining spots coincided. A white spot was observed with the $\mathrm{AgNO}_{3}$ reagent for carbohydrates. After prolonged acid hydrolysis $\left(6 \mathrm{M}-\mathrm{HCl}\right.$ at $110^{\circ} \mathrm{C}$ for $24 \mathrm{~h}$ ) free amino acids, inorganic phosphate and a neutral carbohydrate, subsequently identified as galactose, were released. The unhydrolysed material, which did not react with Coomassie Brilliant Blue G250 (used for estimation of protein), remained at the origin of the chromatographic systems, except those containing phenol when it ran at the solvent front, or $77 \%$ ethanol when an elongated spot with an $R_{F}$ value of about 0.3 was noted.

The presence of anionic groups in the phosphorus-containing compound was established by demonstrating that it migrated towards the cathode in electrophoretic system (a) at pH 1.7 (two spots were observed with relative mobilities of -0.58 and -0.78 ). However, the material also contained cationic groups because it migrated towards the anode (relative mobility +0.40 ) in electrophoretic system (d) at $\mathrm{pH} 10$.

The above observations provided preliminary evidence for the existence in the spermatophoric plasma of a major constituent composed of phosphate bound to one or two peptides, and possibly also to a sugar. Further work was therefore undertaken to elucidate the nature of the phosphate-peptide linkage and to identify the carbohydrate by using a variety of degradative procedures and analytical means. The three main degradation methods were (i) hydrolysis with strong acid, (ii) digestion with enzymes, and (iii) hydrolysis with weak acid and alkali. 
Identification of amino acids, galactose and galactose phosphate as degradation products

Hydrolysis with strong acid $\left(6 \mathrm{M}-\mathrm{HCl}\right.$ at $110^{\circ} \mathrm{C}$ for $\left.24 \mathrm{~h}\right)$, followed by electrophoresis and paper chromatography, led to the identification of the amino acids lysine, histidine, glycine, alanine, valine, serine, threonine, proline, glutamate and aspartate. In most phosphoproteins, phosphate is found bound to serine or threonine residues. However, electrophoretograms of material obtained by controlled $\mathrm{HCl}$ hydrolysis provided no indication for the presence of degradation products migrating in system (a) as phosphoserine or phosphothreonine (relative mobilities of +0.20 and +0.11 ), but they did reveal the presence of a phosphorus-containing substance migrating in a manner characteristic of a sugar phosphate (relative mobility of +0.57 ) and yielding a positive reaction with the $\mathrm{AgNO}_{3}$ stain and the $p$-anisidine reagent for the detection of reducing sugars. In addition, there was present at the origin of the electrophoretogram a compound behaving similarly towards $\mathrm{AgNO}_{3}$ and $p$-anisidine, but lacking in phosphorus. Both spots were eluted and examined further in the chromatography system $(b)$ where they migrated in the same positions as authentic galactose phosphate and free galactose. Prior treatment of the putative galactose phosphate spot with alkaline phosphatase converted it to free inorganic phosphate and a free sugar migrating as galactose. Final confirmation that this sugar was D-galactose was obtained by showing that it reacted with galactose dehydrogenase in the spectrophotometric assay system, and that the conversion product behaved identically to galactonolactone in chromatographic system (b).

Next, an attempt was made to identify the nature of the linkage of galactose phosphate to the peptide chain. No release of inorganic phosphate, galactose or galactose phosphate followed from treatment of the parent compound with alkaline phosphatase, phosphodiesterase, $\alpha$-galactosidase, $\beta$-galactosidase or $\beta$-glucosidase. However, steric hindrance may have prevented some of these enzymes from acting. Therefore, other procedures were tested for their ability to reduce the parent compound to smaller units.

Amongst a variety of proteases, pronase proved to be the most effective; after electrophoresis of the degradation products in system (a), two ninhydrin-positive and phosphorus-containing compounds (relative mobility -0.66 and -0.78 ) were isolated from other phosphorus-negative compounds. These phosphorus-containing fragments yielded galactose and galactose phosphate on acid hydrolysis and contained little aspartate or glutamate.

When the parent compound was treated with weak acid (1.5 M-acetic acid) or weak alkali ( 1 $\mathrm{M}-\mathrm{NH}_{4} \mathrm{OH}$ or $\left.0.1 \mathrm{M}-\mathrm{NaOH}\right)$ at $110^{\circ} \mathrm{C}$ for $24 \mathrm{~h}$, both procedures yielded, among other products, a phosphorylateó product which was electrophoretically neutral at $\mathrm{pH} 1.7$ and was ninhydrin-negative but $\mathrm{AgNO}_{3}$-reactive. This material was further purified by electrophoresis in system (c) (relative mobility of +0.69 ). It yielded galactose phosphate but no galactosamine after short acid hydrolysis $\left(1 \mathrm{~h}\right.$ at $110^{\circ} \mathrm{C}$ in $\left.1 \mathrm{M}-\mathrm{HCl}\right)$ and glycine, valine and glutamate after prolonged acid hydrolysis $\left(17 \mathrm{~h}\right.$ at $110^{\circ} \mathrm{C}$ in $\left.6 \mathrm{M}-\mathrm{HCl}\right)$. Despite reducing the parent compound to this simpler fragment, the fragment remained unaffected by alkaline phosphatase or phosphodiesterase.

Distribution of the organically-bound acid-soluble phosphorus in reproductive-tract tissue and fluids, and its participation in the spermatophoric reaction

Table 1 lists the results of analyses of inorganic and total acid-soluble phosphorus in trichloroacetic-acid extracts prepared from several body fluids and tissues of the male octopus, and from the plasma separated by centrifugation from the sperm ropes of spermatophores at different stages of maturation. Organically-bound phosphorus can be taken as the difference between total acid-soluble phosphorus and inorganic phosphorus. As can be seen from Table 1, the high content of acid-soluble phosphorus, which is comprised almost exclusively of organically-bound phosphorus, characterizes only the mature spermatophore. 
The question whether during the spermatophoric reaction any of the organically-bound acid-soluble phosphorus can pass across the outer tunic of the spermatophore, from the intra-spermatophoric milieu into the sea water, was investigated. A spermatophore freshly removed from the spermatophoric sac was placed in a tray filled with $1000 \mathrm{ml} 2 \cdot 7 \%(\mathrm{w} / \mathrm{v}) \mathrm{NaCl}$ (equivalent to that of sea water) and allowed to undergo a complete spermatophoric reaction at $10^{\circ} \mathrm{C}$; it took $1 \mathrm{~h} 50 \mathrm{~min}$ for the spermatophore to balloon out into the spermatophoric bladder. The total acid-soluble phosphorus contents were $17.2 \mathrm{mg}$ in the spermatophoric-bladder plasma $(24 \mathrm{ml}), 7 \mathrm{mg}$ in the plasma left behind in the bladder, i.e. in the tube of the spermatophore $(8 \mathrm{ml})$, and $3.6 \mathrm{mg}$ in the total volume of the external medium $(974 \mathrm{ml})$ :

\section{Discussion}

The high content of organically-bound acid-soluble phosphorus in the spermatophoric plasma of the octopus was shown by the present study to be largely derived from a trichloroacetic acid-soluble phosphoglycopeptide which contains galactose phosphate. The amino acid composition of the peptide, notable for the absence of aromatic acids, bears some resemblance to that of the "dialysable peptide fraction" described in an earlier study of the octopus spermatophoric plasma, which also showed that, in addition to the peptide-bound amino acids, some bound aminosugar is present in dialysates from spermatophoric plasma (Mann et al., 1970; Hanson, Mann \& Martin, 1973).

Analyses of the degradation products of the purified phosphoglycopeptide indicate that the linkage of the galactose phosphate moiety to the peptide is via the phosphoryl group, possibly to glutamine, rather than via a glycosidic linkage of the galactose. Consistent with this view are several observations, and in particular the fact that no free inorganic phosphate is released by treatment with alkaline phosphatase, no galactose phosphate is formed upon treatment with phosphodiesterase or glycosidases, and the simplest degradation product is devoid of amino acids with hydroxyl groupings (serine, threonine). However, more work would have to be done to establish the precise composition and configuration of the galactophosphopeptide.

From the data contained in Table 1 it can be seen that the high content of acid-soluble phosphorus characterizes only the mature spermatophore with little of it being found in plasma from either the vesicular- or prostatic-spermatophore. Presumably, therefore, this high concentration is formed during the final stage of spermatophore development, at the time when the intraspermatophoric fluid undergoes condensation. It would seem unlikely that this organically-bound phosphorus originates in either the blood or genital-bag fluid, because their acid-soluble phosphorus content is very low. The material may be secreted by the glandular epithelia of the male reproductive tract and be subsequently concentrated during the final stages of spermatophore development and maturation. Another possibility is that the galactophosphopeptide is a natural derivative or large-molecular weight glycoproteins which abound in the spermatophoric plasma; proteolytic enzymes and highly active glycosidases are present in this fluid (Mann, Karagiannidis \& Martin, 1973).

About $13 \%$ of the acid-soluble phosphorus passed across the outer tunic of the spermatophore and entered the sea water in the course of the spermatophoric reaction in vitro. Part of this material may have been accounted for by glycerophosphocholine which is another characteristic constituent of the octopus spermatophoric plasma (Brooks et al., 1974) and is readily dialysable. However, a relatively high proportion of the organically-bound phosphorus passed a cellophane membrane during dialysis, albeit over a dialysis period of $36 \mathrm{~h}$, which is much longer than the $1 \frac{1}{2}-2 \frac{1}{2} \mathrm{~h}$ period usually needed for a spermatophore to complete the spermatophoric reaction in vitro or in vivo. It is also probable that the behaviour of the highly basic galactophosphopeptide might be significantly influenced by ionic and/or hydrophobic interactions with other components of the spermatophoric plasma. 
The part of this investigation carried out at the Department of Zoology of the University of Washington was supported by Grant PCM 74-09402 from the National Science Foundation, U.S.A.: T.M. thanks the Royal Society for a travel grant from the Browne Research Fund.

\section{References}

Berenblum, I. \& Chain, E. (1938) XL. An improved method for the colorimetric determination of phosphate. Biochem. J. 32, 295-298.

Bergmeyer, H.U. (1974) Methods of Enzymatic Analysis, 2nd edn. Academic Press, New York.

Bligh, E.G. \& Dyer, W.J. (1959) A rapid method of total lipid extraction and purification. Can. J. Biochem. Physiol. 37, 911-917.

Block, R.J., Durrum, E.L. \& Zweig, G. (1958) A Manual of Paper Chromatography and Paper Electrophoresis, 2nd edn. Academic Press, New York.

Brooks, D.E. (1970) Acid-soluble phosphorus compounds in mammalian semen. Biochem. J. 118, 851-857.

Brooks, D.E., Mann, T. \& Martin, A.W. (1974) The occurrence of carnitine and glycerylphosphorylcholine in the octopus spermatophore. Proc. R. Soc. Lond. $B$ 186, 79-82.

Brown, D.M., Clark, B.F.C. \& Letters, R. (1961) Phospholipids. Part VII. The structure of a monophosphoinositide. J. Chem. Soc. 3774-3779.

Dawson, R.M.C., Hemington, N. \& Davenport, J.B. (1962) Improvements in the method of determining individual phospholipids in a complex mixture by successive chemical hydrolyses. Biochem. J. 84, 497-501.

Dawson, R.M.C., Elliott, D.C., Elliott, W.H. \& Jones, K.M. (1969) Data for Biochemical Research, 2nd edn, p. 541. Clarendon Press, Oxford.

Efron, M.L. (1968) High voltage paper electrophoresis. In Chromatographic and Electrophoretic Tech- niques, 2nd edn, Vol. 2, pp. 166-193. Ed. I. Smith. Heinemann, London.

Hanson, D., Mann, T. \& Martin, A.W. (1973) Mechanism of the spermatophoric reaction in the giant octopus of the North Pacific, Octopus dofleini martini. J. Exp. Biol. 58, 711-723.

Harrap, F.E.G. (1960) The detection of phosphate esters on paper chromatograms. Analyst (Lond.) 85, 452.

Hough, L. \& Jones, J.K.N. (1962) Chromatography. [6]. Chromatography on paper. In Methods in Carbohydrate Chemistry, Vol. 1, pp. 21-31. Eds R. L. Whistler \& M. L. Wolfrom. Academic Press, New York.

Mann, T., Martin, A.W. \& Thiersch, J.B. (1970) Male reproductive tract, spermatophores and spermatophoric reaction in the giant octopus of the North Pacific, Octopus dofleini martini. Proc. R. Soc. Lond. $B$ 175, 31-61.

Mann, T., Karagiannidis, A. \& Martin, A.W. (1973) Glycosidases in the spermatophores of the giant octopus, Octopus dofleini martini. Comp. Biochem. Physiol. 44A, 1377-1386.

Sedmak, J.J. \& Grossberg, S.E. (1977) A rapid, sensitive, and versatile assay for protein using Coomassie Brilliant Blue G250. Analyt. Biochem. 79, 544-552.

Toennies, G. \& Kolb, J.J. (1951) Techniques and reagents for paper chromatography. Analyt. Chem. 23, 823-826.

Trevelyan, W.E., Procter, D.P. \& Harrison, J.S. (1950) Detection of sugars on paper chromatograms. Nature, Lond. 166, 444-445. 